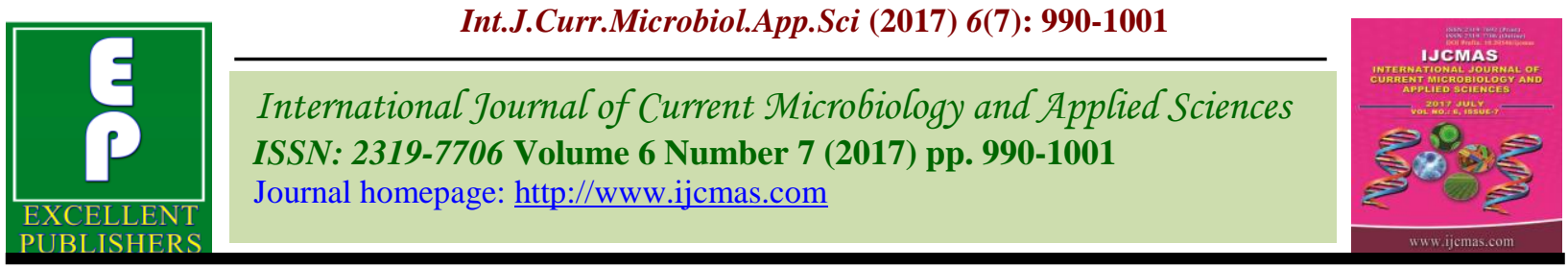

Original Research Article

https://doi.org/10.20546/ijcmas.2017.607.120

\title{
Advanced Design for Generation of Electricity in Rotary Mode Operation Using Animal Power
}

\author{
J.R. Rajeshwar ${ }^{*}$ and Anshuka Srivastava ${ }^{2}$ \\ ${ }^{1}$ CTAE, MPUAT, Udaipur-313001, India \\ ${ }^{2}$ Mechanical Department, SHIATS, Allahabad-211007, India \\ *Corresponding author
}

\section{A B S T R A C T}

\begin{tabular}{|l|}
\hline K e y w o r d s \\
Animal power, \\
Electricity, \\
Rotary mode \\
operation, \\
Dynamo. \\
\hline Article Info \\
\hline $\begin{array}{l}\text { Accepted: } \\
\text { 14 June } 2017 \\
\text { Available Online: } \\
\text { 10 July } 2017\end{array}$ \\
\hline
\end{tabular}

Livestock have been used in agriculture for thousands of years supplying energy for crop production in terms of draught power and organic manure. But due to mechanization in agriculture, the role of animals in crop production became less relevant. But in a country like India where $78 \%$ of farmers have less than 2 ha of area for cultivation, the question whether the use of tractors and tillers are economical put forward the importance of draught animals in agriculture. It is assumed that one pair of draught animals develop approximately 750 watts of power. If the million animals can be used, say, for about 250 days of a year at the rate of $6 \mathrm{hrs}$ per day, then the total energy available will be 45 million mw hr. it has been estimated that average use of animal power in a year is only 100 year days. In this research a modified machine design and developed for the generation of the electricity with the help of draught animal in rotary mode operation and The average speed, draft force and power requirement of a pair of bullocks were $2.5 \mathrm{~km} / \mathrm{h}, 730 \mathrm{~N}$ and $0.18 \mathrm{~kW}$ to operate the animal driven electricity generator for electricity generation and battery charging.

\section{Introduction}

Energy crisis in the world will be one of the factors to impede the economic growth of both developing and developed countries. Agriculture sector plays a key role in the overall economic development and social well being of the country. It is observed that in the last few decades, the underground water levels have been falling down drastically and the cultivated land area has been on the increase due to destroying of the forests. Hence, there is growing demand for electrical energy for irrigation. The generation is not growing proportionately to the growing demand. On the other side, the available energy is also not properly utilized for agricultural purposes. The farmers have to be educated in the area of energy conservation and proper utilization of available resources in the country. The Electric Power Survey of India that is done regularly helps forecast demand of electricity and serves as an important input for power sector planning so as to utilize the scared resources optimally.

According to International Energy Agency (IEA) data from 1990 to 2008, the average energy use per person increased $10 \%$ while world population increased $27 \%$. And as of 2010, about $16 \%$ of global final energy consumption comes from renewable but at the 
same time the fossil fuels (liquid, coal and natural gas) have been the primary energy source for the present day world which is of non-renewable energy system. So the renewable as well as non-renewable energy system both is important for human development

Electrical energy in India currently has peak demand storage of around 14\% and an energy deficit of $8.44 \%$. keeping this in view and to maintain a GDP(Gross Domestic Products) growth of $5 \%$ to $10 \%$ the government of India has very prudently set a target of $215,804 \mathrm{mw}$ power generation capacity by march 2001 from the level of $100,010 \mathrm{mw}$ as on march 2001 that us 0 capacity addition of 115,794 mw in the next 11 years. The average rate of increase of energy consumption in India is 6\% per year. The power transmission network at present covers about $45 \%$ of the villages with about $67 \%$ of rural population. Centralized energy sources thus have made very little penetration in the rural areas, and even it is penetrated, the supply position has been highly unreliable, particularly during the period of peak operations.

Draught animals power (DAP) play a dominant role in our rural economy. Although an increasing mechanization is replacing the animal power in the villages, reducing the total DAP, yet India has to depend on animal energy for many years to come from agricultural operations transport of farm product. The draught animal power has not been found adequate and, thus this is being supplemented by mechanical power, especially for tillage, irrigation and threshing. It is assumed that one pair of draught animals develop approximately 750 watts/hour of power. If the million animals can be used, say, for about 250 days of a year at the rate of 6 hrs per day, then the total energy available will be 45 million $\mathrm{mw} \mathrm{hr}$. it has been estimated that average use of animal power in a year is only 100 year days. Therefore it is obvious that at present the draught animal power is not being utilized to greater extent there are still large number of villages in the plain regions in general and hilly areas in particular which have no electricity power supply. So if we use these draught animals for the generation of the electricity for whole year then they provide electrical energy to the farmers for their daily household use. Now these draught animals will not be any burden to the farmers due to the useful source of electric energy. So farmers will be able to utilize the draught animal for the generation of electricity and store it in a battery as well as for doing other works also such as extraction of sugarcane juice or pulling the bullock kart etc. By this utilization of the animals, the problems of power would be reduced.

The main objective of this paper is to generate electricity with the help of animal power in rotary mode and to store the generated electricity in the batteries.

\section{Materials and Methods}

\section{Draught animals}

In India bullocks are main draught animals. Bullocks have very good characteristics as draught animals, yet they are far from being employed to their full capacity. A pair of bullock pulls the tongues in the machine in a circular motion. Bullocks can walk for 4-5 hours continuously. These animal powers are normally more available and affordable to people in rural areas and fragile environments.

\section{Modified mechanical gear unit}

While earlier studies based on animal power made use of gear reduction units in which the gear reduction obtained was considerably less. It was felt that such a conventional gear 
reduction unit could not be used for the generation of electricity by animal power as electricity generated would not feasible economically and performance wise. So, it was desired to use a modified mechanical gear unit, which would be more feasible option for study. The details of this modified mechanical gear unit are given. This unit gave a speed ratio of 1:30.875 in second stages. In third stages, finally gave the speed ratio of $1: 617.5$ at the input of the alternator due to attach the belt and pulley arrangement.

\section{Mechanical link}

Mechanical link of mild steel material having $52 \mathrm{~mm}$ diameter and $230 \mathrm{~mm}$ length with extended extra strong GI pipe of $3000 \mathrm{~mm}$ length and $4.5 \mathrm{~mm}$ wall thickness.

\section{Speed increaser}

Speed increaser is a four set of spur gears housed in a frame of mild steel angles having $690 \mathrm{~mm} \times 690 \mathrm{~mm}$ at the top and $780 \mathrm{~mm} \times$ $780 \mathrm{~mm}$ at bottom. It is having 4 numbers of stages with gear ratio of $1: 4.5$. Input shaft of the speed increaser having $50 \mathrm{~mm}$ diameter and $600 \mathrm{~mm}$ length of mild steel material is in vertical position whereas output shaft having $50 \mathrm{~mm}$ diameter and $450 \mathrm{~mm}$ length of mild steel material of the same is also in vertical position. The shafts are supported with taper roller bearings at top and bottom. Bearings are fastened on tie-bars which are welded on frame. Speed increaser is specially used for transmitting and converting low-speed high torque to high-speed low-torque.

\section{Gears}

Four sets of spur gears transmit the power among parallel shafts. The spur gears are made of cast iron (Sut $=320 \mathrm{~N} / \mathrm{mm} 2)$ having module $5 \mathrm{~mm}$. the spur gears has 68 teeth while the spur pinions has 15 teeth. The pressure angle is 20 degree and outside diameters are $350 \mathrm{~mm}$ and $85 \mathrm{~mm}$ respectively.
The speed ratio of 1:4.5 is obtained in single stage.

\section{Belt and pulley system}

The final speed increasing is done by using belt and pulley system. One pulley of $228.6 \mathrm{~mm}$ (9 inch) was mounted on the output shaft of the speed riser and counter pulley was mounted on car alternator having $76.2 \mathrm{~mm}$ (3 inch) thereby stepping up the speed in the ratio 1:3 when connected with belt. According to Indian Standard Code (IS: 2494-1974), the A type of belt is selected which has power ranges $0.7 \mathrm{~kW}-3.5 \mathrm{~kW}$.

\section{Magnetic alternator}

The alternator is a device used to convert mechanical energy into electrical energy. In this experiment, the input pulley is powered by the output shaft of the gear unit with the help of belt and pulley arrangement. The relative motion between magnetic field and armature induces electromotive force which further causes the establishment of electrical potential, i.e. voltage. This alternative current (A.C.) produced is conveyed to output wires with the help of commutator of alternator. The output capacity of the alternator is 1KVA. Single phase, $50 \mathrm{HZ}$ AC alternator was used for this system.

In this experimental study we select the car alternator to generate electricity. Lucas-TVS car alternator of $12 \mathrm{~V}$ and $95 \mathrm{AH}$ is used. Car alternator needs high rpm to work efficiently. It produces constant voltage but current depends on rpm and produce high as rpm is high.

\section{Dynamo system}

In 1866, Werner von Siemens discovered the electro-dynamic principle, which today forms the basis for our electricity generation. If you move an electric conductor, such as a wire, in 
a magnetic field, this creates an electric voltage in the wire. If you connect the ends, current flows. This is the principle used to create electricity in generators. In the example above, the magnetic field (red) rotates and thus creates alternating voltage in the yellow conductors. Technicians call this a "dynamo". This principle is utilised in the same way by both bicycles and the rotating axes of turbines in power plants. A typical dynamo consists of one or more permanent magnets with a coil rotating inside their poles. The stationary part of the device is called the stator, while the rotating bit is known as the armature. When the coil is spun in the magnetic field produced by the permanent magnets, the magnetic flux starts to vary through the coil, creating an electric field which in turn drives the charge carriers through the wire, generating an electric current (Fig. 1.

\section{Stabilizing unit}

The produced current is stabilized and supplied to the main circuit. Also the required voltage is maintained through Automatic stabilizer.

\section{Battery}

In this experiment a typical $12 \mathrm{~V}$ and $40 \mathrm{AH}$, 100AH, 150AH, 180AH, Lead-acid automotive battery is used. An automotive battery is a type of rechargeable battery that supplies electric energy. It shows 12.6 volt at full charge and at fully discharged: $11.8 \mathrm{~V}$. Charging time depends on the capacity of that battery and the resting voltage of that battery when you begin to charge it. If battery is $50 \%$ or more full, it takes less time to charge.

\section{Fabrication and procedure}

The fabrication of speed increaser was done very carefully because there are five vertical shafts which are supported by taper roller bearing. The bearing covers were fitted with the help of nut and bolt on the mild steel ties, which are welded on the frame at top and bottom. Collars are provided at bottoms of shaft to support the load on bearings.

Gears are fitted by means of nuts by drilling two holes on the shafts and on gear houses. There are four step gear transmission system. The first gear of 68 teeth was mounted on first shaft at $20 \mathrm{~mm}$ from the collar which meshes with the second gear having 15 teeth mounted on second shaft at $20 \mathrm{~mm}$ above from the collar. The third gear having 68 teeth was mounted on second shaft $50 \mathrm{~mm}$ above the second gear and meshes with the fourth gear having 15 teeth which was mounted on third shaft at the same height. The fifth gear having 68 teeth was mounted on third shaft $50 \mathrm{~mm}$ above the fourth gear and meshes with the sixth gear having 15 teeth which was mounted on the fourth shaft at the same height. The seventh gear having 68 teeth was mounted on fourth shaft $50 \mathrm{~mm}$ above the sixth gear and meshes with the eighth gear having 15 teeth which was mounted on fifth shaft at same height. The pulley of $228.6 \mathrm{~mm}$ was mounted on fifth shaft at $200 \mathrm{~mm}$ from the bottom which drive the another pulley of $76.2 \mathrm{~mm}$ mounted on alternator and alternator was fabricated on the frame with the help of mechanical linkage. Authors selected the car alternator for generating electricity which has the ideal speed of $2000 \mathrm{rpm}-6000 \mathrm{rpm}$. Animal have very low speed $(\mathrm{v}=1 \mathrm{~m} / \mathrm{s})$ [1-5]. When animal rotates at radial distance $(r)$ of $2.5 \mathrm{~m}$ from the main shaft (first gear) then the distance at one revolution is $15.7 \mathrm{~m}(2 \times \pi \times$ $2.5)$. And the distance cover in one minute by animal is $1 \times 60=60 \mathrm{~m}$. Hence the initial $\mathrm{rpm}$ is 3.82 (60/15.7). Due to compatibility and resources available author selected the gears used in sugarcane juice machine of speed ratio 4.5. Four stage gear system was used. Output rpm is increased by using pulley and belt which has speed ratio 3. So the rpm of output gear according to S SRatan (2004). 
$\frac{N_{g}}{N_{1}}=\frac{Z_{1}}{Z_{2}} \times \frac{Z_{g}}{Z_{4}} \times \frac{z_{5}}{z_{6}} \times \frac{z_{7}}{z_{g}}$

$\left(N_{f}\right) g=3.82 \times 4.5 \times 4.5 \times 4.5 \times 4.5 \approx$

1567

Before staring the experiment the alternator was connected with battery and ampere meter was jointed in series. The mechanical link GI pipe was fitted with the first shaft of speed increaser by means of elbow and nut-bolt at one end and another end was coupled on belan with the help of GI wire such that the centre of belan coincide at $2500 \mathrm{~mm}$ of mechanical link. The speed increaser was fixed in the pit of $780 \mathrm{~mm} \times 780 \mathrm{~mm} \times 300 \mathrm{~mm}$. When the man started moving into the circular path and also the belan along with mechanical link rotated the first shaft of the speed increaser.

At the starting the rpm was very low hence the alternator was not responding but as well as speed was increasing the alternator started to generating power. The rpm and generated volt \& current were taken after every four minutes. In this experiment seven automotive batteries of $12 \mathrm{~V} 40 \mathrm{AH}, 100 \mathrm{AH}, 150 \mathrm{AH}$, $180 \mathrm{AH}$ were charged with animal power system. The batteries were charged from different states of charge i.e. $25 \%, 50 \%$, and $75 \%$.

\section{Rotary power transmission unit}

The unit has bevel and spur gears to raise the slow moving speed of animals (average 2 $\mathrm{rpm})$ to $20 \mathrm{rpm}$. Output shaft of bevel and spur gear transmitted power to the input shaft of gearbox. The gear box unit consists of a box of size $970 \mathrm{~mm}$ x $560 \mathrm{~mm}$ x $510 \mathrm{~mm}$ made out of $10 \mathrm{~mm}$ thick M.S. Plate. In the gear box one input shaft, two intermediate and one output shaft with helical gears were arranged in such a way that they raised rotational speed of bull gear to 20 times (speed ratio 20: 1). The gears were made of
EN 353 material. The pitch of gear was $6 \mathrm{~mm}$. At the end of output shaft of gearbox Vgroove pulley of $600 \mathrm{~mm}$ diameter was provided and connected with the $\mathrm{V}$-groove pulley of $100 \mathrm{~mm}$ diameter mounted at the alternator. This gave the speed ratio of $6: 1$ between pulley of alternator and outer shaft of gearbox. System resulted about $2400 \mathrm{rpm}$ of alternator, when animals made one revolution around the rotary track. A wooden beam of length $4.2 \mathrm{~m}$ was used at the input shaft of the power transmission system to give drive to gearbox through animal power.

An alternator 24 Volt- 45 amperes was used to generate electricity. The alternator was driven by $100 \mathrm{~mm}$ diameter pulley fitted on the output shaft by the driver pulley of 600 $\mathrm{mm}$ mounted at the output shaft of gearbox. The relative motion between magnetic field and armature induces electromotive force, which further causes the establishment of electric potential, i.e. voltage. This alternating current (AC) produced was conveyed to output wires with the help of commutator of alternator. The electricity generated by alternator was supplied to two batteries and the same is stored in the battery in the form of chemical energy. This stored chemical energy gets converted into electrical energy to give useful work when the electrical load is applied between the two terminals of the battery. Two batteries model AMCO, ABP $1600 \mathrm{P}, 17$ plates, $12 \mathrm{~V}, 150 \mathrm{Ah}$ were used to store the electric generated by the alternator. The two batteries were charged to know the specific gravity of batteries at full charge. At full charge specific gravity of battery was 1250. The charged batteries were discharged by lightening 4 nos 100 watts bulbs for 5 hours and specific gravity of batteries was measured. The discharge batteries were used to charge with animal driven electricity generator. The specific gravity of battery was measured at the start of experiment and after each hours of operation. 


\section{Installation}

The gear reduction unit is installed underground on a cement concrete foundation. The main driving shaft of the gear system was welded to a long iron beam. The bullocks are hitched to this beam at the time of operation. The alternator was place near the output shaft of the gear reduction unit. It is fixed on a solid foundation on the ground by using nuts and bolts to screw it firmly on two iron strips which acted as the foundation for the alternator.

The power transmission unit was installed on a flat surface with RCC. The alternator was placed near the output shaft of the gearbox unit. It was fixed on RCC foundation using nuts and bolts to secure it firmly. The bullocks were hitched to beam at the time of operation. A pair of Malvi breed of bullocks was used for this study.

The body weights of animals used to operate the rotary power transmission system was measured using an electronic weighing machine (capacity $0-1000 \mathrm{~kg}$ ). The average heart girth, average body length, average height and body weight of the experimental bullocks No.1 was 1460 mm, 1480 mm, 1320 $\mathrm{mm}$ and $460 \mathrm{~kg}$ respectively and that of bullock No. 2 was $1570 \mathrm{~mm}, 1660 \mathrm{~mm}, 1380$ $\mathrm{mm}$ and $498 \mathrm{~kg}$ respectively. $21 \mathrm{x}$ micro logger and load cell $(0-1000 \mathrm{~N})$ was used to measure the pull force of the bullocks operating the rotary power transmission unit. The load cell was mounted between the beam and yoke through the rope. The values of pull were recorded after every $5 \mathrm{~min}$. The angle of line of pull (50) and angle of inclination of rope (200) with the line of travel were determined by use of abeney level. The speeds of operation, bull gear rev./min were recorded at the start and after every hour of work. The horizontal component of pull resulted draught force value. Speed of bullocks was determined by recording the time to travel one circle in rotary test track. The power requirement was calculated by using the equation,

$P=\frac{F \times S}{3.6}$

Where, $\mathrm{P}=$ power in $\mathrm{kW} ; \mathrm{F}=$ draught force, $\mathrm{kN}$ and $\mathrm{S}=\mathrm{Speed}, \mathrm{km} / \mathrm{h}$

For rotary power transmission drive it is important to determine torque as well as the number of revolutions (rpm). Accurate torque measurement can provide data for optimizing control and diagnosis of rotary drive systems. For measurements of accurate torque, speed and power output at the output shaft of gear box a DATUM electronics torque transducer (Model DAO3TSP-D), Range-0- 200 N-m was used. The set up for measurement of torque is shown in figure 2. During the test, values of torque, speed and power output at the output shaft of box, rpm of bull gear and pulley mounted at armature shaft of alternator were recorded. The physiological parameters of working bullocks such as heart rate, respiration rate, rectal temperature and fatigue symptoms were recorded at the start of work and after every hour of work. A work rest cycle of $2 \mathrm{~h} \mathrm{~W}-1 \mathrm{~h}$ Rest $-2 \mathrm{~h}-1 \mathrm{~h}$ rest $-2 \mathrm{~h}$ work was followed to measure the physiological responses of bullocks. Observations on physiological parameters were taken by following standard methods i.e. Heart rate (beats/min): By sensing palpitation/min of the animal at coxyoal artery at the rear of tail.

Breathing rate (breaths/min): By counting nos. of air exhaled/min by the animal. Rectal temperature (0C): By inserting a clinical thermometer in the anus $50 \mathrm{~mm}$ inside. The sequence of observations on visual fatigue symptoms were recorded as per the fatigue score card (Upadhyay, 1987). 


\section{Variables under study}

The different variables considered under study were observed at using of A.C. Alternator. The variables are listed below:

\section{Independent variables}

These variables consider under different applied Output loads i.e. $15,20,30,45,60,75,90,105,120$ watt for A.C. Alternator.

\section{Dependent variables}

Input Power $\left(\mathrm{P}_{\mathrm{i}}\right)$

$>$ Output Power $\left(\mathrm{P}_{\mathrm{o}}\right)$

Current (I)

Voltage (V)

Speed $(\mathrm{S})$

Efficiency ( $\mathrm{y})$

The power and efficiency on different loads are calculated by following equations-

Input Power $\left(\mathrm{P}_{\mathrm{i}}\right)=\frac{\operatorname{draft}(\mathrm{kg}) \times \operatorname{spsed}(\mathrm{km} / \mathrm{hr})}{270} \times 746$

Output Power $\left(\mathrm{P}_{\mathrm{o}}\right)=\mathrm{V} \mathrm{I} \cos \theta$

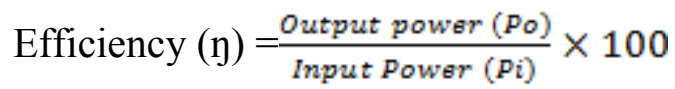

\section{Experimental method}

This chapter deals with all the materials, instruments and equipments used to conduct the project. The basic component which has been used for conversion of rotary mode of animal power to electrical energy is the mechanical gear unit. In this unit, a series of spur gear and bevel pinion have been used to achieve speed step-up of 1:30.875 at output shaft. This output shaft was connected to the alternator input through belt and pulley arrangement, which have been used to achieve total speed of step-up of 1:617.5. We have installed this set-up properly and animal driver had been made to operate a pair of bullocks with $2.4 \mathrm{kmph}$ mean peripheral speed in rotary path.

After this we obtained the value of average draft, which was created by the draught animal power by using dynamometer. The output shaft speed was found in rpm by using tachometer, also found voltage and current by using digital multimeter at the output of the alternator on both no load and different load conditions.

It was stabilized and maintained the required voltage by using automatic stabilizer, which was directly connected to output of the alternator through copper wire.

\section{Results and Discussion}

\section{Electricity generation}

It was feasible to generate the electricity by using draught animal power in rotary mode of operation. In this system, mechanical gear unit and pulley arrangement were used to obtain an overall speed ratio of 1:617.5. The maximum power was found to be 135 watts at $59 \mathrm{~kg}$. This was the maximum load the animals could pull with increased symptoms of physiological physical distress. The output power to input power ratio i.e. efficiency of the system was found to be $50 \%$.

The initial torque and rotational speed of shaft were $19 \mathrm{~N}-\mathrm{m}$ and $54 \mathrm{rev} / \mathrm{min}$ details are shown in table 1 . However the torque reduced as the rotational speed increased from 54 to $470 \mathrm{rev} . / \mathrm{min}$. Due to higher initial torque the draft force produced by the animal was higher and speed of operation was lower at the start of work..The draft force of animals reduced as the torque reduced. Power output was 
maximum $0.28 \mathrm{~kW}$ at $345 \mathrm{rev}$. /min of output shaft of gearbox. Draft force and speed of bullocks were $748 \mathrm{~N}$ and $2.6 \mathrm{~km} / \mathrm{h}$ at $345 \mathrm{rev}$. /min of output shaft of gearbox.

Due to the higher ratio of the teeth of the two cranks the speed steps up in the rotary power transmission system and so the speed of armature pulley of alternator (Table 2). The table revealed that the rotational speed of alternator increased from $1680 \mathrm{rev} . / \mathrm{min}$ to $2375 \mathrm{rev} . / \mathrm{min}$ as the speed of bullocks increased from 2.15 to $3.10 \mathrm{~km} / \mathrm{h}$. As speed of bullocks reached at $2.55 \mathrm{~km} / \mathrm{h}$ the alternator gave the $1970 \mathrm{rev} . / \mathrm{min}$. and produced $26 \mathrm{~V}$, which was sufficient for charging of two battery of $12 \mathrm{~V}$. but when the armature run at below $1795 \mathrm{rpm}$ the alternator produced about $24 \mathrm{~V}$ and from this voltage batteries were not charged properly due to drop of voltage in electrical circuit. So, for proper charging of battery, the animal speed must be above the $2.45 \mathrm{~km} / \mathrm{h}$.

Considering the limitation of speed, the animals were operated in sustained working following the work rest cycle of $2 \mathrm{~h}$ work $-1 \mathrm{~h}$ rest $-2 \mathrm{~h}$ work $-1 \mathrm{~h}$ rest $-2 \mathrm{~h}$ work in day. During the operation of rotary power transmission system to generate voltage for charging of battery the bullocks gave average speed of $2.50 \mathrm{~km} / \mathrm{h}$ and power output of 0.20 $\mathrm{kW}$ under sustained working of $6 \mathrm{~h}$ in a day. The animals were not fatigued as they scored 16 points, 4 points below the fatigue limit i.e. is 20 points.

The average power output at the output shaft of gearbox was $0.26 \mathrm{~kW}$ at $350-400$ $\mathrm{rev} . / \mathrm{min}$. The torque output at this speed varied from 6-8 N-m. A pair of Malvi breed of bullocks gave average power output of $0.48 \mathrm{~kW}$ at the $345-410 \mathrm{rev} . / \mathrm{min}$ of shaft. Substitution of input and output power in equitation (3.3) resulted power transmission efficiency of system as $50 \%$ (Table 3).
It was feasible to generate the electricity by using draught animal power in rotary mode of operation. In this system, mechanical gear unit and pulley arrangement were used to obtain an overall speed ratio of 1:617.5. The maximum power was found to be 135 watts at $59 \mathrm{~kg}$. This was the maximum load the animals could pull with increased symptoms of physiological physical distress. The output power to input power ratio i.e. efficiency of the system was found to be $50 \%$.

The system was tested by means of human power for three times and it was recognized that the initial force (torque) to rotate alternator at idle speed was very low, it can easily operated by using single hand. Before staring the experiment the alternator was connected with battery and ampere meter was jointed in series. The mechanical link GI pipe was fitted with the first shaft of speed increaser by means of elbo and nut bolt at one end and another end was coupled on belan with the help of GI wire such that the center of belan coincide at $2500 \mathrm{~mm}$ of mechanical link. The speed increaser was fixed into the pit of $780 \mathrm{~mm} \times 780 \mathrm{~mm} \times 300 \mathrm{~mm}$. The bullock pair was harnessed with traditional means. When shephered applied force the bullocks started moving into the circular path and also the belan along with mechanical link rotate the first shaft of the speed increaser. At the starting the rpm was very low hence the alternator was not responding but as well as speed was increasing the alternator start to generating power.

Bullocks were need to applied force time to time to maintain average speed. The rpm and generated volt and current were taken after every four minutes. First time the battery was $50 \%$ discharge i.e. $12 \mathrm{~V} 75 \mathrm{AH}$ (approx as indicated by hydrometer) and it took approximate 4 hours to charge fully (hydrometer indicate 12.6V). Second time battery was $45 \%$ discharge and it took four 
hour and some minutes. The experiment done at $60 \%, 65 \%, 70 \%, 75 \%$, and $80 \%$ and $85 \%$ state of charge and time taken to charge fully had taken. Parallelpy the time required to discharge the battery at different percentage when 150 watt AC load was subjected to battery through inverter had taken. The experiment had done 9 times using same bullocks and animal had taken care regularly. At single time 360Watt DC load was subjected to fully charge battery and time taken to discharge it $50 \%$ was two hours and
7 minutes. The animals' effort and speed depend on the load subjected and force applied by shepherd. Animal speed is change very quickly and abruptly. It is very difficult to taking speed reading continuously because animals got puzzled. The readings are taken after every four minutes within one hour and results are shown in graphs. Speed vs. Time graph shows that average speed of alternator is mostly changes, but it is within the ideal working range of alternator.

Table.1 Variation in torque and rotational speed of output shaft of gearbox with the draft force and speed of bullocks

\begin{tabular}{|l|l|l|l|l|l|l|}
\hline $\begin{array}{l}\text { Bullock } \\
\text { s speed } \\
(\mathbf{k m} / \mathbf{h})\end{array}$ & $\begin{array}{l}\text { Draf } \\
\mathbf{t} \\
\mathbf{( N )}\end{array}$ & $\begin{array}{l}\text { Powe } \\
\mathbf{r} \\
\mathbf{( k W})\end{array}$ & $\begin{array}{l}\text { Torqu } \\
\mathbf{e} \\
\mathbf{( N - m )}\end{array}$ & $\begin{array}{l}\text { Rotationa } \\
\text { l speed of } \\
\text { shaft } \\
(\mathbf{r p m})\end{array}$ & $\begin{array}{l}\text { Power } \\
\text { outpu } \\
\mathbf{t} \\
(\mathbf{k W})\end{array}$ & $\begin{array}{l}\text { Efficienc } \\
\mathbf{y} \\
\mathbf{\%}\end{array}$ \\
\hline $\mathbf{0 . 6 8}$ & 1165 & 0.22 & 19 & 54 & 0.10 & 45 \\
\hline $\mathbf{1 . 4 0}$ & 926 & 0.36 & 15 & 145 & 0.18 & 50 \\
\hline $\mathbf{2 . 6 0}$ & 748 & 0.54 & 11 & 345 & 0.28 & 51.8 \\
\hline $\mathbf{2 . 8 0}$ & 630 & 0.52 & 9 & 385 & 0.27 & 51.9 \\
\hline $\mathbf{3 . 0 0}$ & 558 & 0.51 & 8 & 410 & 0.25 & 49.2 \\
\hline $\mathbf{3 . 1 5}$ & 470 & 0.45 & 6 & 425 & 0.22 & 48.9 \\
\hline $\mathbf{3 . 3 2}$ & 340 & 0.37 & 4 & 445 & 0.18 & 48.64 \\
\hline $\mathbf{3 . 4 0}$ & 325 & 0.27 & 2 & 470 & 0.14 & 51.85 \\
\hline
\end{tabular}

Table.2 Speed steps up in rotary power transmission system and produced voltage operated with a pair of bullocks

\begin{tabular}{|l|l|l|l|l|}
\hline $\begin{array}{l}\text { Speed of } \\
\text { bullocks } \\
(\mathbf{k m} / \mathbf{h})\end{array}$ & $\begin{array}{l}\text { Rotational } \\
\text { speed } \\
\text { of bull gear } \\
\text { (rpm) }\end{array}$ & $\begin{array}{l}\text { Rotational } \\
\text { speed at } \\
\text { O/P shaft of } \\
\text { gearbox(rpm) }\end{array}$ & $\begin{array}{l}\text { Speed } \\
\text { armature } \\
\text { pulley } \\
\text { alternator(rpm) }\end{array}$ & $\begin{array}{l}\text { Voltage } \\
\text { produced } \\
\text { (V) }\end{array}$ \\
\hline $\mathbf{3 . 1 0}$ & 22 & 410 & 2375 & 30 \\
\hline $\mathbf{2 . 7 5}$ & 19 & 370 & 2140 & 28 \\
\hline $\mathbf{2 . 5 5}$ & 17 & 340 & 1970 & 26 \\
\hline $\mathbf{2 . 4 5}$ & 16 & 330 & 1910 & 25 \\
\hline $\mathbf{2 . 3 5}$ & 16 & 310 & 1795 & 25 \\
\hline $\mathbf{2 . 2 5}$ & 15 & 300 & 1730 & 24 \\
\hline $\mathbf{2 . 1 5}$ & 14 & 290 & 1680 & 23 \\
\hline
\end{tabular}


Table.3 Speed steps up in rotary power transmission system and produced current operated with a pair of Malvi breed of bullocks

\begin{tabular}{|l|l|l|l|l|}
\hline $\begin{array}{l}\text { Speed of } \\
\text { bullocks } \\
(\mathbf{k m} / \mathbf{h})\end{array}$ & $\begin{array}{l}\text { Rotational } \\
\text { Sped } \\
\text { of bull gear } \\
\text { (rpm) }\end{array}$ & $\begin{array}{l}\text { Rotational } \\
\text { speed at } \\
\text { output shaft } \\
\text { of gearbox } \\
\text { (rpm) }\end{array}$ & $\begin{array}{l}\text { Speed } \\
\text { armature } \\
\text { pulley } \\
\text { alternator(rpm) }\end{array}$ & $\begin{array}{l}\text { Current } \\
\text { produced } \\
\text { (A) }\end{array}$ \\
\hline $\mathbf{3 . 1 0}$ & 22 & 410 & 2375 & 0.90 \\
\hline $\mathbf{2 . 7 5}$ & 19 & 370 & 2140 & 0.85 \\
\hline $\mathbf{2 . 5 5}$ & 17 & 340 & 1970 & 0.72 \\
\hline $\mathbf{2 . 4 5}$ & 16 & 330 & 1910 & 0.58 \\
\hline $\mathbf{2 . 3 5}$ & 16 & 310 & 1795 & 0.44 \\
\hline $\mathbf{2 . 2 5}$ & 15 & 300 & 1730 & 0.36 \\
\hline $\mathbf{2 . 1 5}$ & 14 & 290 & 1680 & 0.30 \\
\hline
\end{tabular}

Fig.1 Electric dynamo

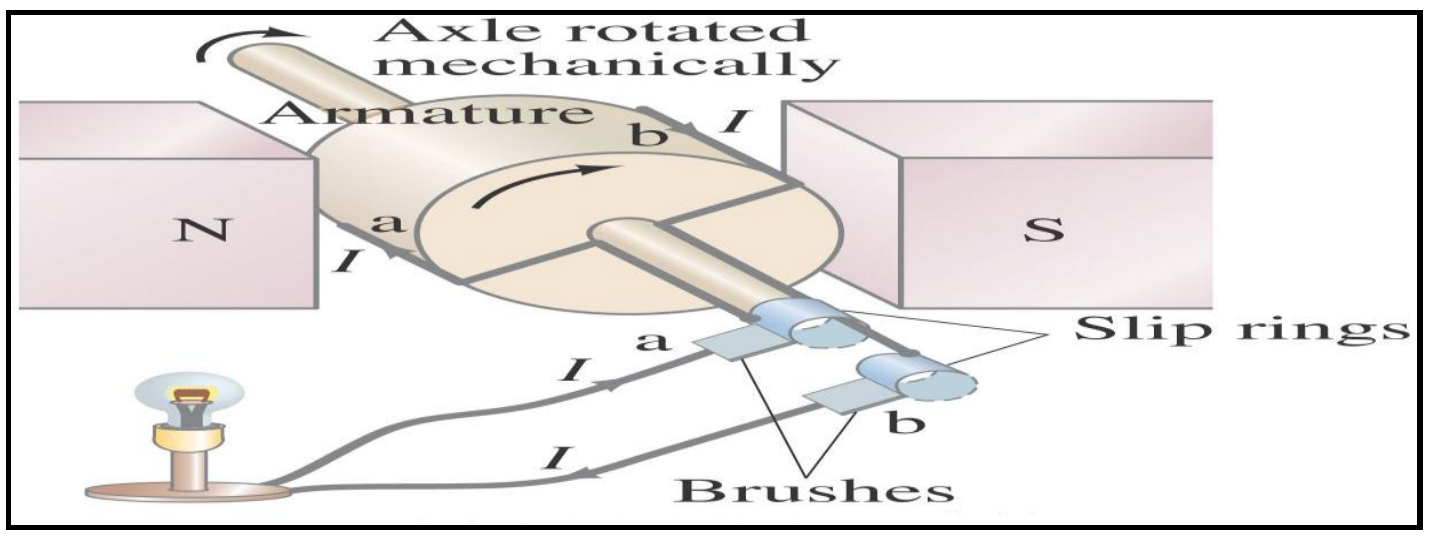

Fig.2 Pull and speed recording of bullock by using $21 \mathrm{X}$ micrologger and load cell

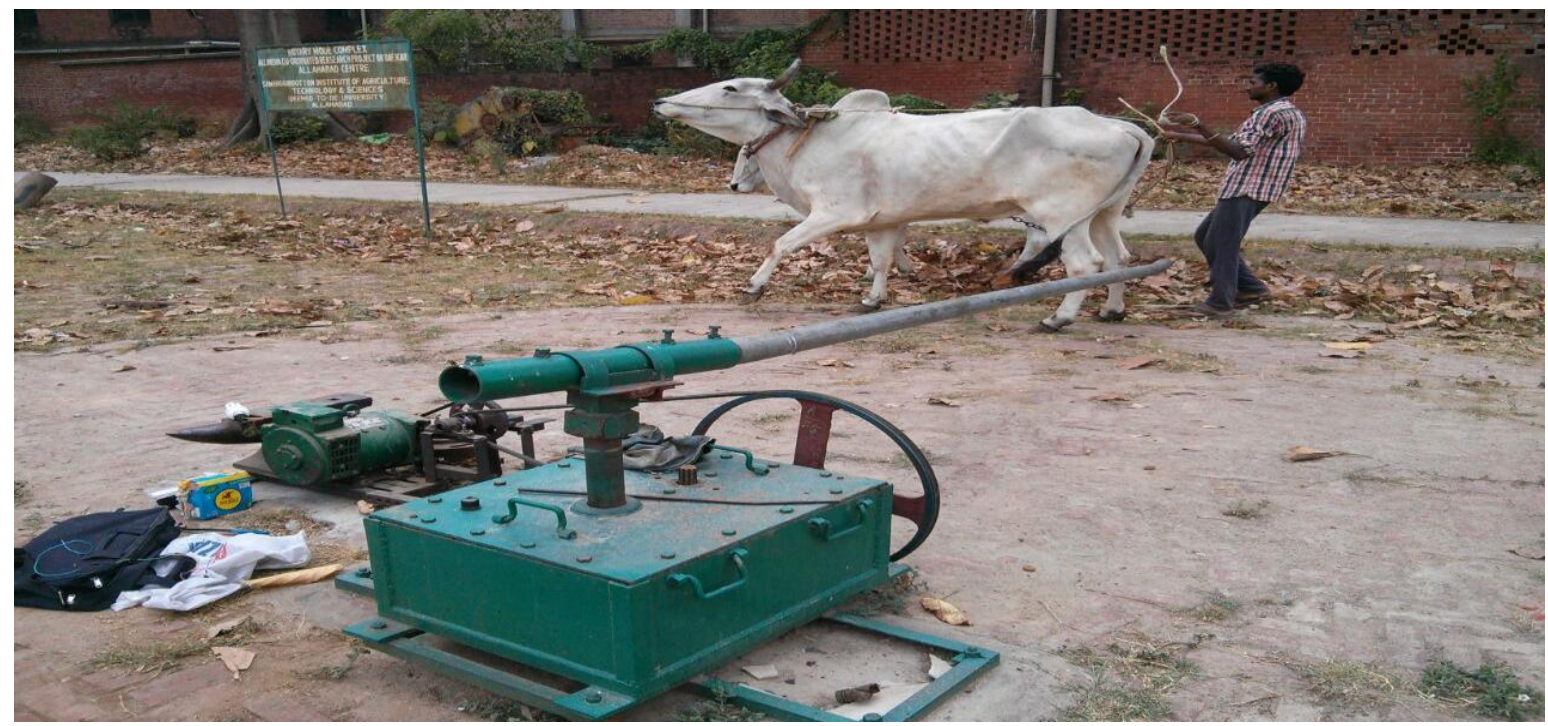


Fig.3 Block diagram of animal powered electricity generator

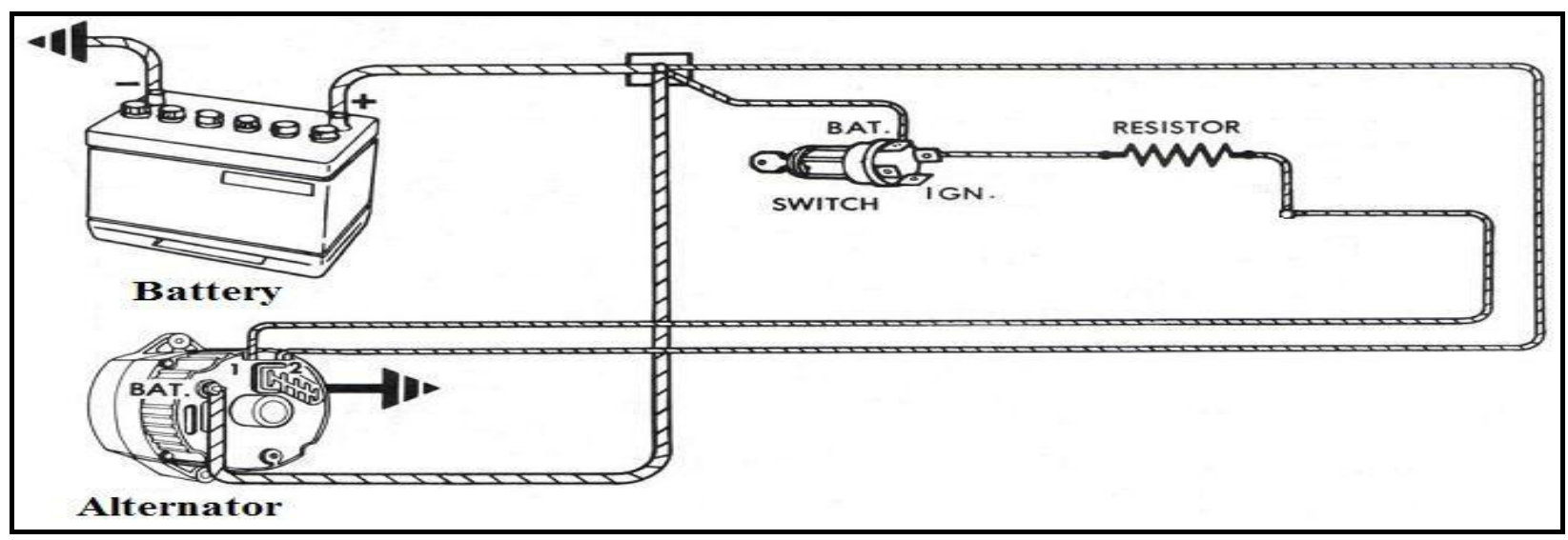

Speed vs. Current shows that at low rpm at starting of animal motion it is not generating current, but as well as rpm is increasing and reaches to ideal working rang alternator producing high value of current.

Experimental result shows that animals take very little time to get their average speed of 0.8 $\mathrm{m} / \mathrm{s}$ to $1 \mathrm{~m} / \mathrm{s}$. But still alternator is not generating current as expected and specified by company due to very quick and abrupt changes in animal speed (Fig. 1). Voltage vs. RPM proves to be completely unchanging as expected and alternator generates constant voltage of $12 \mathrm{~V}$ as specified after reaching ideal speed. State of Charge vs. Charging Time shows that battery takes more time to charge as less as state of charging is low for charging same amount. Fully charged battery shows $12.6 \mathrm{~V}$. Fully charged battery takes the approximately 2 hours and 7 minute to discharge $50 \%$ when 6 bulb of 60Watt DC is loaded. Since alternator takes initial current to energize the battery must not be discharge completely. Lighting Time of 6 CFL bulb of $25 \mathrm{~W}$ AC for different state of discharge is shown in graph. Results shown in the experiments that battery and inverter have more than $80 \%$ efficiency as expected. Finally result was found that at least $4 \mathrm{hrs}(6 \mathrm{pm}-$ $10 \mathrm{pm})$ the home will be lighted using that system. In conclusion, the average speed, draft force and power requirement of a pair of bullocks were $2.5 \mathrm{~km} / \mathrm{h}, 730 \mathrm{~N}$ and $0.18 \mathrm{~kW}$ to operate the animal driven electricity generator for electricity generation and battery charging. The batteries are fully charged after 8 hours of operation of animal driven electricity generator. It was also found that the mechanical efficiency of animal driven electricity generator was $45 \%$.

\section{References}

Anil, K.S. and Thomas, C.K. 1996. Comparative draught performance of cattle and buffaloes: Physiological reactions. Ind. J. Anim. Sci., 66: 398-401.

Considine, D.M. (Ed) 1997. Energy Technology Handbook. McGraw-Hill Book Company.

Dipankar, et al. 2000. Power Availability in Indian Agriculture Technical Bulletin CIAE Bhopal. Draught animals. From (http://www2.sjsu.edu/faculty/watkins/ani malpower.htm) Metric conversion by Tim Lovett.

Fuller, R.J., Aye, L.U. 2012. "Human and animal power - The forgotten renewables" Renewable Energy 48: 326332.

Jain, A.K. and K.N. Gaur. 1996. Enhancement of Value of Farm Produce. Proceedings of National Seinar on Problematique of Technological Transformation of Rural India, I.E.R.T., Allahabad, March, 13-15: 55-58.

Kulkarni, S.D. 2005. Mechanisation of Agriculture- Indian Scenario. Paper presented at the conference on the Technical Committee of APCAEM (21- 
24 November), New Delhi. [accessed: http://

http://www.unapcaem.org/activities\%20fi les/a09105thtc/ppt/in-doc.pdf]

Mersha Chanie, Tewodros Fentahun, Tadegegne Mitiku and Malede Berhan. 2012. European J. Biol. Sci., 4(3): 96104, 2012, ISSN 2079-2085, (C) IDOSI Publications, 2012.

Paras, Singh, V.K. and Chaudhary, A. 2012. Generation of Electricity by Utilization of Power of Draught Animal. Ind.Res. J. Ext. Edu., I: 150-153.

Phaniraja, K.L. and Panchasara, H.H. 2009. Vet. World, Vol 2(10): 404-407.

Rani Alex, Umesh Singh, Rafeeque Rahman Alyethodi, Rajib Deb. 2013. Adv. Animal and Vet. Sci., 1(6): $178-182$ http://www.nexusacademicpublishers.co $\mathrm{m} / \mathrm{journal} / 4$

Shrivastava, N.S.L. 2000. Animate Energy in Agriculture. Agri. Engi. Today, 24(2): pp 13-34.

Shrivastava, N.S.L. and Pandey, M.M. 1992. Design and development of animal loading car for draughtability studies. Ind. J. Agr. Eng., 2(2): 79-84.

Shrivastava, N.S.L., and G.C. Yadav. 1985. Perspective Planning for Draught Animal Power for the Year 2000. Proceeding of the National Seminar on Status of Animal Energy Utilization, Jan. 24-25:327-336.

Singh, G. 1999. Draught Animal Energy Research in India. Proceeding of the Workshop of the Animal Traction Network for Eastern andYadav, S.B., Jogdand, S.R. and D.K. Roy. Southern Africa, Sep 20-24, pp. 315-322.

Singh, G. 2000. Empowering Farmers with Animal Traction. Proceedings of the workshop of the Animal Traction Network for Eastern and Southern Africa
(ATNESA) held 20-24 September 1999, Mpumalanga, South Africa, 344p. ISBN 0-907146-10-4.

Singh, Gyanendra. 2000. Energy Conservation through Efficient Mechanized Farming. Agri. Engi. Today 24(2): pp 35-50.

Singh, R.C. and Singh, D.C. 2009. Effect of age and body size on the work output of Malvi and crossbred oxen. Ind. J. Anim. Sci., 79(8): 850-852

Singh, R.S. and S.R. Singh. 2003. Development and Propagation of Bullock operated Generator. Final Report of Adhoc Research Scheme Submitted to IC A R. Department of Agriculture \& Cooperation, Ministry of Agriculture, Government of India.

Upadhyay, R.C. and Madan, M.L. 1987. Work capacity speed and effect of sustained work on crossbred and Haryana bullocks. Ind. J. Dairy Sci., 40(I): 28-41.

Van niekerk, H.R., Hancke, G.P. 1999. An animal powered electricity generator for standalone applications 939 - 942 vol.2, IEEE AFRICON-5th Africon Conference in Africa.

Wilson, R.T. 2003. The environmental ecology of oxen used for draught power. Agri. Ecosystems and Environ., 97: 211-37.

Yadav, G.C. and B.D. Shukla. 1987. Animal Power Based Agricultural Processing in Villages. Utilization and economics of Draught Animal Power, Technical Bulletin CIAE-87-51, pp 282-285. 2003. Draught animal power in Chhattisgadh, Technical bulletin No FAE/UAE/2003. Indira Gandhi Krishi Vishwa Vidyalaya, Raipur.

\section{How to cite this article:}

Rajeshwar, J.R. and Anshuka Srivastava. 2017. Advanced Design for Generation of Electricity in Rotary Mode Operation Using Animal Power. Int.J.Curr.Microbiol.App.Sci. 6(7): 990-1001. doi: https://doi.org/10.20546/ijcmas.2017.607.120 